\title{
Responsibility to Protect (R2P) and the Emerging Principle of Common Concem
}

\section{Krista Nadakavukaren Schefer and Thomas Cottier}

\section{Abstract}

This paper conceptualises the emerging concepts of responsibility to protect (R2P) and common concem. Beyond exploring the foundations of these two concepts, it explains their current interaction and how they may be developed further in the future. The principle of common concem responds to obvious institutional deficiencies in producing global public goods. It obliges states to cooperate in the pursuit of such goods, such as climate change mitigation and adaption. Failing such cooperation, it empowers states to act accordingly. We argue that R2P may be understood as a particular category of common concem, encompassing not only the right, but more importantly, a lso the obligations to act in case of gross human rights violations. Linking R2P and common concem will allow their role in addressing the shortcomings of traditional precepts of intemational law to evolve without increasing the potential of misuse by placing limits on their invocation.

Research for this paper was funded by the Swiss National Science Foundation under a grant to the National Centre of Competence in Research on Trade Regulation, based at the World Trade Institute of the University of Bern, Switzerland. 


\title{
Responsibility to Protect (R2P) and the Emerging Principle of Common Concern
}

\author{
Krista Nadakavukaren Schefer and Thomas Cottier*
}

DRAFT 31.5.2012

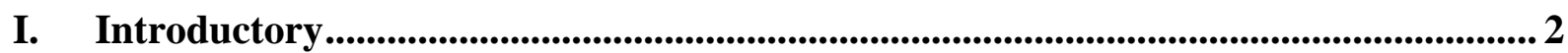

II. The Traditional Paradigm, its Failures, and Solutions........................................4

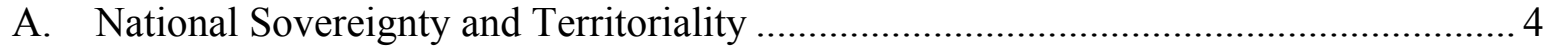

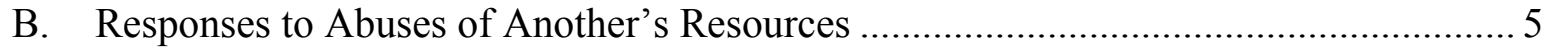

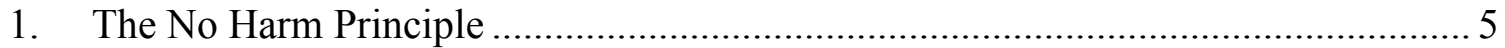

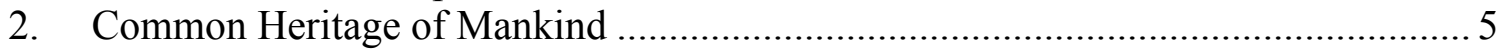

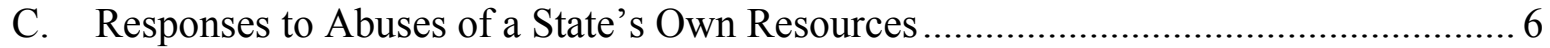

1. Recognizing Global Interest in Environmental Harms .......................................... 6

2. Human Rights and the Right of Humanitarian Intervention .................................... 6

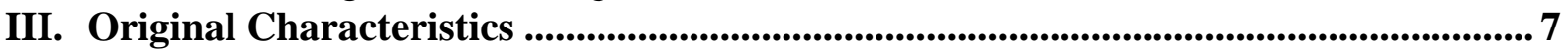

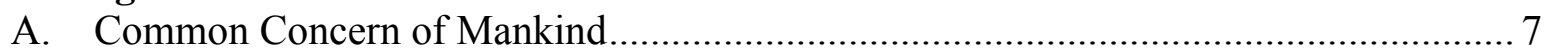

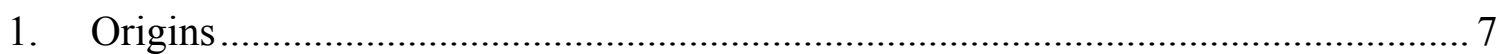

2. Elements of Common Concern as Originally Conceived ..................................... 8

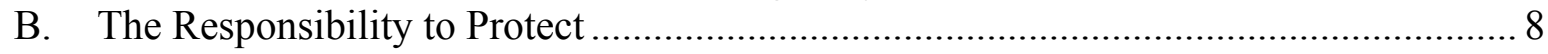

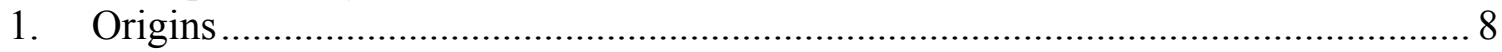

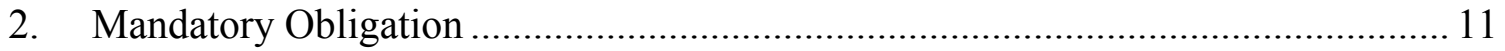

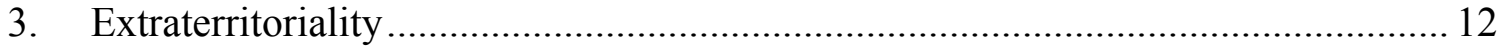

C. The current Relationship of Common Concern and R2P ........................................... 13

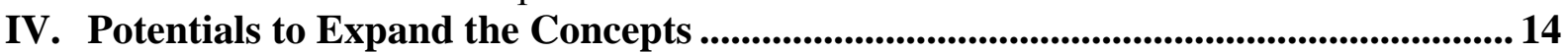

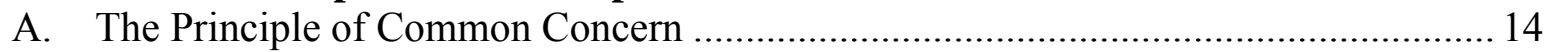

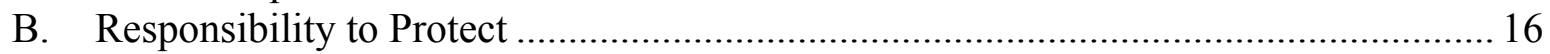

\section{Introductory}

Despite the protestations of the diplomatic community, the introduction of a responsibility to protect as a norm binding states does not merely amount to a step along the existing trajectory of international legal development. In fact, it is our opinion that there have been few international principles developed over the last 50 years that would, if implemented, so

\footnotetext{
* We are indebted to Kateryna Holzer, Dannie Jost, Baris Karapinar, Rachel Liechti, Joelle de Sépibus, Nashina Shariff and Anirudh Shingal, all of the World Trade Institute, University of Bern, for critical comments. The responsibility remains our own.
} 
radically alter the existing legal framework of state relations as that of the emerging Responsibility to Protect (R2P). A Paradigmenwechsel? Yes, potentially, but not yet.

The same holds true for Common Concern of Mankind, or briefly Common Concern. It originated earlier than R2P. The concepts both emerged from an original impulse of recognizing the international system as a community. Both are premised on a belief in the mutual interest of all people in the well-being of all people without regard to political boundaries or legal jurisdictions. As cosmopolitan concepts, they both call upon states to address situations of the human condition that are extraterritorial as well as those within their territories. In this, R2P and Common Concern share the need to overcome traditional approaches to state sovereignty, both in their labeling of problems and in the scope of their responses.

Structurally, both R2P and Common Concern are concepts that were born in response to a particular type of problem but which are potentially adaptable to a much wider range of problems. While Common Concern as a concept was from the beginning less narrowly focused than the carefully limited R2P principle, Common Concern 's applicability so far has remained limited to a small handful of environmental problems and has never quite made it beyond a preambular-exhortation into a widely recognized legal principle or norm in either political or academic circles. R2P's scope in its current form is carefully circumscribed to an enumerated set of situations as well. While this narrowness is not essential (and, as we shall argue below, is in fact harmful) to the concept as a legal norm, it has been thought to be so in terms of political acceptability. Indeed, its invocation by the United Nations (UN) General Assembly (GA) and Security Council (SC) and individual states lend strength to scholarly calls for noting its importance.

The topic to be addressed, R2P and Common Concern, is one that could be approached in many ways, but we shall address just one angle: showing that R2P is a particular type of Common Concern issue. The significance of this relationship is that it underlines the common philosophical base of the principles while also placing an important limit on the scope of R2P actions.

Following a short description of the traditional international law paradigm and its failures, this Chapter will set out the two concepts of R2P and Common Concern individually, noting their original characteristics. We note how the two concepts differ in their impact on the international legal system of today. For Common Concern, the most significant element has been its focus on problems that necessarily must be addressed by the international community in joint co-operation. So far, it does not yet entail responsibilities of individual states to act giving effects beyond their borders, and powers to take action extraterritorially remain controversial. Responsibility to Protect, on the other hand, is characterized by its demand for positive actions on the part of governments to address international concerns. Next, we focus on the potential for expanding the concepts beyond their drafters' viewpoints. Recognizing that R2P's potential to significantly improve the protection of individuals if the concept is broadened, leads us to examine its legitimate boundaries. We find these limits in the concept of Common Concern. R2P applies to a subset of Common Concern issues, which places an important limit on states" permissible invocations of "responsibility" when intervening in other states' jurisdiction. Fears of excessive intervention can thus be eased. At the same time, we explore the impact of $\mathrm{R} 2 \mathrm{P}$ on Common Concern in terms of state responsibility and 
suggest refining the doctrine to move towards a principle equally entailing responsibilities of States to act on behalf of the international community.

\section{The Traditional Paradigm, its Failures, and Solutions}

\section{A. National Sovereignty and Territoriality}

The Westphalian system of sovereign states has as its basis the strong notion of territoriality. This implies the territorial state's jurisdiction to consume and regulate resources within that state's physical boundaries. The jurisdiction, significantly, is exclusive: as all governments are equal, each state's sovereignty-implied jurisdiction extends no farther than another's - to the recognized borders of the states' respective territories.

The problems with Westphalian sovereignty, however, became apparent during the $20^{\text {th }}$ Century. One of these problems was what to do when a state's actions taken within its territory had extraterritorial effects, harming either another state's resources or resources that were denoted non-sovereign. The issues of transboundary pollution, pollution of the high seas, over-fishing, and space debris are all examples of where the traditional territorial sovereignty frameworks fail to uphold the interests of the international community vis-à-vis the sovereign state.

A separate problem, however, arose when a sovereign abused resources within its own territory. The deforestation of areas with abundant biodiversity, the destruction of the habitat of endangered species, or the abuse of citizens' human rights are all examples of actions that are "domestic concerns" for sovereign governments when sovereignty is defined territorially. Under an increasingly cosmopolitan view of international relations, however, such abuses could - if severe enough - actually be a violation of the interests of the international community. But for too long, the interests of the international community were no match for the rights of the sovereign state.

The solutions that arose in response to these two problems were similar but distinct. The abusive effects of a state's territorial actions on another sovereign's resources led to the development of the no harm principle as a norm of customary international law and the idea that the problems caused by such actions should be addressed in terms of the doctrine of Common Heritage of Mankind, limiting states' jurisdiction to act on their own and to their exclusive benefit in exploiting natural resources. The state's actions harming its own resources required the development of sovereignty-agnostic concepts. These developed along two paths, one, recognizing a global interest in the environmental problems caused by a state's sovereign misuse of its resources and one creating an expanded framework for extraterritorial state action to address problems caused by another state's abuse of human and humanitarian rights. 


\section{B. Responses to Abuses of Another's Resources}

\section{The No Harm Principle}

The no harm principle prohibits states from using or permitting their territory to be used in a way that will damage another sovereign's resources. Set out famously in the Trail Smelter award $^{1}$, this principle is now codified in numerous international environmental instruments, including the 1997 United Nations Convention on the Non-Navigational Uses of Transboundary Watercourses, which contains as its Article 7 ("Obligation not to cause appreciable harm") the provision: "1. Watercourse States shall, in utilizing an international watercourse in their territories, take all appropriate measures to prevent the causing of significant harm to other watercourse States" and the Biodiversity Convention, where Article 3 places on the Parties the "responsibility to ensure that activities within their jurisdiction or control do not cause damage to the environment of other States or of areas beyond the limits of national jurisdiction". 2 These duties to prevent the incurrence of harm, either by not acting or by regulating, were a small step away from the complete version of territorial sovereignty (as the state was required to act within its territory, even if it would not have done so absent an international obligation), but it was a step necessary to uphold the territorial sovereignty of another state.

\section{COMmon Heritage of MANKInd}

The abusive effects of territorial actions on a non-sovereign resource led to the promotion of the doctrine of Common Heritage of Mankind. This doctrine attempts to offset the "tragedy of the commons" ${ }^{\prime 3}$ by establishing administrative mechanisms for sharing the benefits of nonsovereign resources. The resources of the Area (the mineral deposits in the seabed below the High Seas) and those of the moon, for instance, are available for private extraction, but any commercial profits or educational advances from such extraction under the original concept guiding the drafters the LOS Convention must be shared with the international community as a whole. The Common Heritage solution is one that poses minimal threats to territorial sovereignty, given that declared common heritage resources are by definition in nonsovereign spaces.

\footnotetext{
${ }^{1}$ The Trail Smelter case (United States, Canada), 16 April 1938 and 11 March 1941, RIAA VOLUME III pp. 1905-1982, at 1965 ("no State has the right to use or permit the use of its territory in such a manner as to cause injury by fumes in or to the territory of another or the properties or persons therein, when the case is of serious consequence and the injury is established by clear and convincing evidence").

${ }^{2}$ United Nations Convention on Biological Diversity (Rio de Janiero, 5 June 1992).

${ }^{3}$ See Garrett Hardin, The Tragedy of the Commons: The population problem has no technical solution; it requires a fundamental extension in morality., 162 Science 1968, pp. 1243-1248 (explaining the tragedy of the commons as the result of the fact that the "individual benefits as an individual from his ability to deny the truth [that his actions will harm the sustainability of the commons] even though society as a whole, of which he is a part, suffers.")..
} 


\section{Responses to Abuses of a State's Own Resources}

The solution to the problem of abuse of sovereign rights was more revolutionary: it was the development of ways to deny - or at least to ignore - absolute territorial sovereignty.

\section{RECOGNIZING GLOBAL INTEREST IN ENVIRONMENTAL HARMS}

Growing awareness of "the environment" as an interrelated system of biological resources and physical forces began to claim widespread attention in the second half of the twentieth century. While the no harm principle was promoted to address transboundary pollution, the science of "the greenhouse effect" brought to light the possible effects of human activity on a public good something no one had before considered a "resource": the climate. Recognizing the public character of the issue, an answer to the question of addressing climatic change would have to be found by the global community as a whole, with the participation of multiple layers of groupings - the international community, states, communities, private persons - and from multiple perspectives: the natural sciences, economics, politics, sociology, and law among others. ${ }^{4}$ Depletion of biological diversity was another problem of international, or "common", concern. There again, multiple actors and multiple perspectives were required to even ask the right questions as to where to begin to resolve the problem.

Not denying state sovereignty as such, questions of "common concern" are agnostic to Westphalian versions of sovereignty. This is due to the global nature of common concern problems - their resolution will neither be found in sovereignty nor in the denial of sovereignty itself, although sovereignty claims can hinder effective progresss on the search for solutions. Common concerns can only be addressed by means of communal efforts at multiple levels with each actor recognizing the significance of its actions as a part of the overall solution.

\section{HUMAN RightS AND THE RigHT OF HUMANITARIAN INTERVENTION}

The law of human rights and debates on the right of humanitarian intervention were the first truly legal steps in the direction of denying sovereignty-as-control claims of states. Imposing on states rules on how to treat citizens, as human rights did, was a significant step for the development of international law as a system. Human rights protection began to be seen as a part of sovereignty rather than as an exception to it. ${ }^{5}$ The debates arising out of the humanitarian catastrophes of the 1990s, in scholarship as well as in the United Nations, followed the trajectory already established by human rights: that each individual deserves

\footnotetext{
${ }^{4}$ See Thomas Cottier, The Emerging Principle of Common Concern: A Brief Outline, in: E.U. Petersmann ed. Multilevel Governance of Interdependent Public Goods: Theories, rules and institutions for the central policy challenge in the 21 st Century (forthcoming).

${ }^{5}$ See, e.g., Jürg Paul Müller, Wandel des Souveränitätsbegriffs im Lichte der Grundrechte, in: R. Rhinow, S. Breitenmoser, and B. Ehrenzeller, eds., Fragen des internationalen und nationalen Menschenrechtsschutzes 45 (1997); Anne Peters, Humanity as the A and $\Omega$ of Sovereignty, 20:3 Europ. J. Int'1 L. 513 (2009); Henry Shue, Limiting Sovereignty in: Jennifer M. Welsh, ed., Humanitarian Intervention and International Relations 11-28 (Oxford: Oxford Univ. Press, 2004).
} 
protection from state abuse. This implied, in the case of serious human rights abuses, first, the possibility of recognizing an international interest in stopping such abuses; and second, the possibility of enforcing the international interest through uses of force.

While UN Members were hesitant to embrace humanitarian intervention in the 1991 Iraqi refugee crisis and were careful to characterize the 1992 Somali action as "exceptional", the numerous internal conflicts that occurred throughout the decade prompted an "emergent norm to protect citizens from the collapse of legitimate state institutions" ${ }^{6}$ For proponents of humanitarian intervention, the decisive argument was that intervention to protect the citizens of another state from the actions of their territorial government could be permitted on the theory that a state is only fully sovereign if it upholds the rights of its citizens. Intervention, then - even military intervention - is not a violation of the overriding principle of sovereignty, because the abusive government has no true "sovereignty" to violate. The same would be true if the government was unable to protect its citizens from non-governmental perpetrators of human rights violations.

Yet, the solutions only addressed the question of whether states have a right to intervene. It was the concept of R2P that made the path breaking jump to a duty to act outside a state's own territory to prevent, halt, or remedy abuses.

\section{Original Characteristics}

\section{A. Common Concern of Mankind}

\section{ORIGINS}

Preceding the emergence of the concept of R2P by thirteen years, the idea of approaching extraterritorial environmental problems as issues of "Common Concern" to mankind was made explicit in UN General Assembly Resolution 43/53 on climate change. ${ }^{7}$ Malta's delegation had suggested the concept as a way to overcome the legal limitations of climate change: climate, a resource under no state's sovereignty, but affecting every state (though changes to climate would affect some more than others), was not a traditional object for protection through environmental law. Even the rules on transboundary pollution would not adequately address the need for prevention and liability arising from a highly complex interplay of factors differentially impacting the overall climate in not entirely foreseeable

\footnotetext{
${ }^{6}$ Nicholas J. Wheeler, The Humanitarian Responsibilities of Sovereignty: Explaining the Development of a New Norm of Military Intervention for Humanitarian Purposes in International Society in: Jennifer M. Welsh, ed., Humanitarian Intervention and International Relations 29-51, 36 (Oxford Univ. Press: New York, 2004)

${ }^{7}$ Protection of global climate for present and future generations of mankind, A/RES/43/53, 70th plenary meeting (6 December 1988), see Thomas Cottier, Sofya Matteotti, International environmental law and the evolving concept of 'Common Concern of mankind', in: Thomas Cottier et al. eds, International Trade Regulation and the Mitigation of Climate Change, Cambridge: Cambridge University Press 2009 p. 21-47.
} 
ways. It is, according to one author, a concept to focus on the sharing of burdens rather than dividing benefits. ${ }^{8}$

\section{Elements of COMMON CONCERn AS ORIGINALly CONCEIVED}

Tolba's Note to the Group of Experts meeting in Malta in 1990 sets out the early conceptions of what exactly was behind labeling climate change a "Common Concern of mankind". Importantly, the idea of a Common Concern is that it is a way of addressing a problem. That means it is neither a concept looking at distribution of resources nor a concept of liability at the outset. While issues of Common Concern may have distributional aspects (sharing of the burden), and while liability may affect the division of efforts to address the problem (requiring burden sharing to be equitable), the key characteristic of the original concept of Common Concern is its need for a multi-party solution. The Note sets out three particularly significant elements of the concept that highlight this conception: first, that a Common Concern is a problem that affects humanity as a whole; second that such problems ought to "be approached in a global framework"; and third, that the label does not affect states' sovereignty claims over territories affected by the problem. ${ }^{9}$ In terms of the recognition of global interdependence, none of these elements is necessarily tied to environmental problems, although the environment offers the clearest example of scientifically proven physical interrelationships.

Moreover the Note emphasizes the "spatial" and "temporal" and "social" aspects of Common Concern problems. The spatial element means that it is important that the global community see the problem as equally (or nearly equally) important to each as well as to all. While some societies may be more heavily impacted by the problem's effects than are others, the problem itself must be one that each agrees is a significant one for the world. Temporally, the idea is that the concern is one for the long-term security of humankind. Adding the intergenerational element to the concept, future generations' well-being as well as that of current populations are therefore to be included as motivations for action. It also looks at the time span of the problems - the challenges labeled Common Concern are themselves ones that may have (detrimental) effects long in the future, making their effects uncertain. Finally, the social aspect of Common Concern is equally broad - the relevant actors are everyone: all levels and branches of governments, non-governmental organizations, the private sector, and groups of individuals are all called upon to be involved in the concern for others.

\section{B. The Responsibility to Protect}

\section{ORIGINS}

The Responsibility to Protect is both a principle and a concept. As a principle, R2P is a norm that is circumscribed by the international community's acceptance of responsibility to protect

\footnotetext{
${ }^{8}$ Mostafa K. Tolba, "The Implication of the 'Common Concern of Mankind' Concept on Global Environmental Issues" 13 Revista IIDH 239 (1991) (note by Executive Director of UNEP, to the Group of Legal Experts, Malta, 13-15 December 1990).

${ }^{9}$ Tolba at $237-238$.
} 
populations facing mass human rights violations. This norm arose out of the broader concept of the need to rescue populations facing threats to their security. The concept of R2P, then, is a recognition that where large numbers of people are threatened with severe and avoidable harm, inaction by those who could assist in reducing that threat is not legitimate. Thus, while the principle of R2P focuses on the responsibility of states, the concept centers on the victims' impending harm.

Responsibility to Protect as a concept had its origins in the African Union's Constitutive Act, which establishes "the right of the Union to intervene in a Member State pursuant to a decision of the Assembly in respect of grave circumstances, namely: war crimes, genocide and crimes against humanity". ${ }^{10}$ Labeled the "non-indifference" principle, the African Union's (AU) right to intervene is a call for regional governments to respond to serious human rights abuses occurring in the territory of others. A clear switch from the nonintervention principle adhered to by AU predecessor the Organization of African Unity, the non-indifference principle has a political importance the reaches beyond its legal proscription to address "grave circumstances". ${ }^{11}$ By permitting governments to scrutinize each other's actions' consistency with human rights principles, it opened the door to not only diplomatic criticism, but also to other African states" "courteous and united interference" directed at stopping neighbors' human rights violations. ${ }^{12}$ African Union members are to be neither limited to nor satisfied by "observing and issuing communiqués". ${ }^{13}$ Rather, they need to be willing to send military troops where necessary to prevent bloodshed or to stop the loss of human lives. ${ }^{14}$ Yet, while conflict avoidance, peacemaking, peacekeeping, and rebuilding are all acknowledged aspects of the non-indifference principle, Chairman of the AU Commission Konare has also called upon non-indifference to encourage financial assistance in relieving the effects of famine. ${ }^{15}$ Equally significant is the active use of the principle: in Burundi in 2003, in the Cormoros in 20007, in Kenya in 2007/2008, and in Zimbabwe in 2008, the African Union took decisions and engaged in direct diplomatic (and in the case of the Comoros, military) intervention in circumstances that were not "grave" according to the legal

\footnotetext{
${ }^{10}$ African Union, Constitutive Act Art. 4(h) (Adopted at Lome, Togo on 11 July 2000).

${ }^{11}$ Tim Murithi, The African Union's Transition from Non-Intervention to Non-Indifference: An Ad Hoc Approach to the Responsibility to Protect? 1 IPG 90, 94 (2009) (calling the policy of non-indifference a "paradigm shift").

${ }^{12}$ Alpha Oumar Konare, Opening Speech addressed to the $10^{\text {th }}$ Ordinary Session of the Executive Commission of the African Union (reported on in "Konare Seeks "Non-Indifference Principle in Africa" 25 January 2007; text available at http://www.panapress.com/Konare-seeks--non-indifference--principle-in-Africa--12-502178-20lang2-index.html).

${ }^{13} \mathrm{Id}$.

${ }^{14} \mathrm{Id}$.

${ }^{15}$ Solomon A. Dersso, “Africa Should Come to the Aid of Somalis - Applying the AU's Principle of NonIndifference” 10 August 2011 (text available at http://www.polity.org.za/article/africa-should-come-to-the-aidof-somalis---applying-the-aus-principle-of-non-indifference-2011-08-10).
} 
definition set out in Article 4. ${ }^{16}$ This latter aspect will be discussed further below ${ }^{17}$, for while the internalization of the non-indifference principle among African governments is far from complete $^{18}$, it does indicate an expansion of the scope of the concept beyond the de lege lata boundaries.

As a principle ("the provisions of paragraphs 138 and 139 of the 2005 World Summit Outcome Document regarding the responsibility to protect populations from genocide, war crimes, ethnic cleansing and crimes against humanity"19), R2P has been affirmed repeatedly by the UN Security Council. Its dictates are strictly limited to situations in which "mass atrocity crimes" are taking place or are likely to take place. The scope of "mass atrocity crimes" accepted by the United Nations members is clear: large scale ethnic cleansing, genocide, war crimes, and crimes against humanity. R2P only applies, as a principle, to situations where one of these four crimes appears or is likely to arise.

A significant aspect of R2P scholarship is the narrowness of its scope and the firm adherence to traditional views on the exclusivity of UN Security Council authorizations of any use of military force. Not only are the triggers limited to the four crimes, but reactions are restricted to the use of diplomatic persuasion, economic coercion, or multilaterally approved forceful actions. The ICISS Report's call for broader notions of the "security" threats facing populations (including poor health, lack of food or shelter, crime, and environmental degradation $^{20}$ ), as well as former Secretary General Annan's similar attention to "human

\footnotetext{
${ }^{16}$ See Murithi, supra, at 95-101.

${ }^{17}$ See infra---

${ }^{18}$ See Paul D. Williams, From Non-Intervention to Non-Indifference: the Origins and Development of the African Union's Security Culture, 106 African Affairs 253,275-8 (2007) (recalling that despite African leaders' support of UNSC Resolution 1674, there was no action taken to intervene in the Sudan crisis and Congo's President Sassou-Nguesso, who used a coup d'état to come to power - was Chair of the AU in 2006).

${ }^{19}$ Resolution 1674 (2006) Adopted by the Security Council at its 5430th meeting, on 28 April 2006, S/RES/1674, para. 4 (2006). See also S/RES/1970 (26 February 2011) (Recalling the Libyan authorities' responsibility to protect its population); S/RES/1973 (17 March 2011) ("Reiterating the responsibility of the Libyan authorities to protect the Libyan population"); S/RES/1706 (31 August 2006) ("Recalling ... [Resolution] 1674 (2006) on the protection of civilians in armed conflict, which reaffirms inter alia the provisions of paragraphs 138 and 139 of the 2005 United Nations World Summit outcome document").

${ }^{20}$ ICISS, The Responsibility to Protect, paras. 2.22-2.23 (December 2001) ("One of the virtues of expressing the key issue in this debate as "the responsibility to protect" is that it focuses attention where it should be most concentrated, on the human needs of those seeking protection or assistance. The emphasis in the security debate shifts, with this focus, from territorial security, and security through armaments, to security through human development with access to food and employment, and to environmental security. The fundamental components of human security - the security of people against threats to life, health, livelihood, personal safety and human dignity - can be put at risk by external aggression, but also by factors within a country, including "security" forces. Being wedded still to too narrow a concept of "national security" may be one reason why many governments spend more to protect their citizens against undefined external military attack than to guard them against the omnipresent enemies of good health and other real threats to human security on a daily basis.
}

2.23 The traditional, narrow perception of security leaves out the most elementary and legitimate concerns of ordinary people regarding security in their daily lives. It also diverts enormous amounts of national wealth and human resources into armaments and armed forces, while countries fail to protect their citizens from chronic 
security" were demonstrably rejected by the Secretary-General Ban Ki Moon's 2009 report, Implementing the Responsibility to Protect. ${ }^{21}$ Paragraph 10(b) of that Report notes:

“(b) The responsibility to protect applies, until Member States decide otherwise, only to the four specified crimes and violations: genocide, war crimes, ethnic cleansing and crimes against humanity. To try to extend it to cover other calamities, such as HIV/AIDS, climate change or the response to natural disasters, would undermine the 2005 consensus and stretch the concept beyond recognition or operational utility".

The principle of R2P as a guard against the four specified crimes was confirmed in the July 2011 General Assembly meetings, where Members indicated "little or no opposition to the principle. ... The critics' focus was on tactics, not on principles or strategies". ${ }^{22}$

While the professed limit is clear, the concept of R2P remains open. It - like Common Concern - has taken on a much less rigid attitude among those who are not focused on its particular implementation within the UN system. For scholars and civil society, the impulses that spurred R2P's acceptance for the narrow set of circumstances have been embraced as a platform for redirecting international law. This occurrence, despite the repeated protestations of diplomatic observers and some scholars, is natural: concepts of this significance, ones which have the potential to be adapted in multiple contexts that need addressing, cannot be artificially strait-jacketed by calls to confine intellectual creativity to the given parameters. Indeed, the Honorable Garth Evans' statements as to the "very specific responsibility" at issue in the accepted view of R2P bases his categorization of the specificity on the political fact of bridging "the divide" between global leaders over the questions of the limits of state sovereignty.

While not denying the practicality of limiting the R2P principle to being a response to a clearly pressing need for removing legal barriers to humanitarian intervention, $\mathrm{R} 2 \mathrm{P}$ is not only a response to state's unwillingness to intervene in another sovereign's affairs on behalf of a foreign population in the sense of being an exception to a prohibition on intervention. Rather, it is a principle that imposes on states an obligation to act extraterritorially - potentially against their will.

\section{MANDATORY OBLIGATION}

The potential strength of the positive obligation inherent in the principle of R2P is its hallmark. It is also critical to the effectiveness of the principle. Without R2P as a demand for action, the term would add nothing new to international legal practice: the jurisprudence of

insecurities of hunger, disease, inadequate shelter, crime, unemployment, social conflict and environmental hazard.").

${ }^{21} \mathrm{~A} / 63 / 677$ (12 January 2009).

${ }^{22}$ Edward C. Luck, The Responsibility to Protect: The First Decade, 3 Global Responsibility to Protect 387,389 (2011). 
the ICJ has already recognized the right of states to address serious human rights violations ${ }^{23}$; the Security Council can already authorize intervention for threats to peace and security, and it has already found such threats where governments were engaged in severe violations of human rights. In cases of genocide, then, existing principles could resolve the question of "whether" the international community "may" act. The problem left is whether the international community "must" act. It is there that R2P becomes critical. Without that, speaking of a Responsibility to Protect would be "lediglich eine Veränderung im linguistischen Sinne" - a changing of labels rather than content. ${ }^{25}$ As such, it would be a worthy focus of its critics, as it could not resolve the problems it was intended to resolve avoiding the situation (such as occurred in Rwanda) in which states could intervene legally but do not want to do so.

\section{EXTRATERRITORIALITY}

Beyond the mandatory action aspect of R2P, the extraterritorial nature of the positive obligation is of novel importance to the international legal system. Placing positive duties on states to protect their own populations from deprivations of human rights has already been discussed in the international law framework. The triple "respect, protect, and fulfill" aspects of such rights automatically requires the state to take steps and contribute resources to ensuring that rights - civil, political, economic, social, or cultural - are able to be enjoyed. ${ }^{26}$ "Doing something", in and of itself, is thus not particularly new for human rights protection in general. In the context of obligations to act to protect the human rights of foreign individuals, however, positive duties become much more striking.

The question of whether we have "duties to distant strangers" is, in current Western society at least, strongly accepted as an ethical principle. ${ }^{27}$ While many argue about the effectiveness of

\footnotetext{
${ }^{23}$ See Christopher Verlage, Responsibility to Protect 375 (Tübingen: Mohr Siebeck, 2009) (citing, among others, Boisson de Chauzournes, Hilpold, and Stahn as critics of the idea that R2P is anything new in international legal thought).

${ }^{24}$ We are leaving aside the question of whether R2P demands individual states are to act. While the dangers of unilateral misuse of the concept of R2P as a remedial measure are serious, the Secretary General's words in the context of states' obligations to inform of possible threats of genocide within the context of R2P's "duty to prevent" pillar are noteworthy: "Presumably this reluctance will fade as Governments come to understand that the responsibility to protect is both an individual and collective one." Report of the Secretary General, Early warning, assessment and the responsibility to protect, A/64/864, para. 12 (14 July 2010).

${ }^{25}$ Verlage at 375 .

${ }^{26}$ The 1997 Maastricht Guidelines on Violations of Economic, Social, and Cultural Rights spoke to the nature of state obligations concerning such rights. The group of experts gathered for that meeting noted that the obligations to respect, protect, and fulfill such rights require the state Party to both act (or to refrain from acting) and to achieve a result of providing for the right. Guideline 15 is particularly noteworthy, setting out as it does, the violation of rights "through omission". See 1997 Maastricht Guidelines on Violations of Economic, Social, and Cultural Rights, para. 15 (Maastricht 1997).
}

${ }^{27}$ For an excellent discussion and account of statist and cosmopolitan theory see Laura Valenti, Justice in a Globalized World, Oxford: Oxford University Press 2011. 
overseas aid, there is broad agreement that one should help others regardless of where the person in need lives or whether she is known to one. ${ }^{28}$ Legal duties to strangers exist in the domestic law of many countries, but, at least in terms of extraterritorial duties, are absent on the international level. Again, there is a critical difference between state rights to protect distant strangers and state obligations to protect these individuals. While one can find evidence for the former, the latter is simply absent as a binding rule of international law. It is because of this that the solidification of a "hard" norm of a Responsibility to Protect would be so noteworthy.

\section{The Current Relationship of Common Concern and R2P}

Emphasizing the problematic nature of a phenomenon and giving states a right to act for the sake of the international community, the concept of Common Concern has aspects that overlap with R2P. Indeed, it is tempting to think that perhaps the two concepts are like humans and apes: sharing the same evolutionary impulse, but going down separate developmental trajectories. Both can be rooted in the principle of non-indifference. Yet, a closer examination of the two concepts, in fact, demonstrates that the differences between them are perhaps more significant than their similarities - at least for now. This does not mean that they cannot be mutually supporting, however, and the following tries to show how these two different concepts can be used together.

One of the strengths of the concept of Common Concern of mankind is its relative imperviousness to non-implementation. It is a concept to push for authority to act and for binding obligations to be made to resolve a problem of international import; it is not yet an obligation to require any action itself, except for that subset of areas that are R2P concerns. Thus, the failure to create such obligations to act does not in itself reduce the inherent value of the Common Concern concept. While the UNEP Secretariat emphasized the need for actors to concretize the content of Common Concern in legal instruments, fearing that otherwise the concept could "rest as just a vague political formula, which could be used to legitimize lack of concrete actions by simply declaring an environmental concern" 29 , in fact it would not be a failure of the concept as such to only "recognize" that a problem is one that concerns the international community, but rather it would be that its legal enforceability would be damaged. Certainly, the idea of Common Concern has normative aspects, but this idea today is more descriptive than programmatic. As such, it lends the principle of Common Concern a measure of robustness as a political idea that is independent of its legal authoritativeness.

As to R2P, any continued refusal to act where the principle would be applicable can be seen as a failure of the principle, because the point of the principle is to force action. This, clearly, is the greatest weakness of the currently limited view of R2P today. Given the gravity of the situations to which R2P applies, the likelihood of its successful invocation is low. Indeed, as Peters notes, "the real problem is not that the United Nations would intervene too often, but that the Security Council has abstained from authorising military activities even in situations

\footnotetext{
${ }^{28}$ Peter Singer, The Drowning Child and the Expanding Circle, The New Internationalist (1997) (text available at www.utilitarian.net; last viewed 17 May 2012).

${ }^{29}$ UNEP at 246.
} 
where the qualitative threshold for triggering what later became called R2P had been reached". ${ }^{30}$ The failure of not only the African Union (in the early years of the nonindifference policy), but also of the international community to effectively address Janjaweed's atrocities in Darfur is the most poignant example of this weakness. Recent Security Council references to the state's "responsibility to protect" during the crises of Libya (March 2011) and Cote d'Ivoire (March 2011), pointed out by some as successes of the principle - were, from another perspective, illustrations of the difficulties in developing effectiveness of the principle further. While the Security Council heeded its own duty to permit UN Members to "take all necessary measures ... to protect civilians", it did not require them to do so. ${ }^{31}$

\section{Potential to Expand the Concepts}

\section{A. The Principle of Common Concern}

Given the increasing number of problems that affect the global community as a whole, the scope of Common Concern of Mankind and its traditional limitation to a political concept of joint action of States needs to be revisited. Common Concerns, as matters transgressing the proper domain of single states, are inherently linked to the experience that territoriality is not in a position to produce important global public goods which, by definition, are available to all and consumption does not diminish the asset (non-excludable and non rivalrous). ${ }^{32}$ Such global goods of global community interest not only entail the obvious case of climatic conditions and global commons, but equally the preservation of international peace, the rule of law, secured market access rights and non-discrimination, and the protection from genocide and hunger and fundamental human rights. States are obliged to support these concerns within their jurisdictions. But these goods often transgress the realm of the nation states and cannot be properly produced on the basis of territoriality of States. They call for concentrated efforts at levels of governance beyond the nation state. Common Concern therefore not merely serves as a foundation of co-operation, but also as a foundation for joint responsibilities in the production of global public goods. It therefore offers a foundation for future obligations to cooperate.

Any situation which can be considered a problem that (1) concerns the entire international community and that (2) cannot be solved by a single member of the community affected within its own borders and means, should be considered one in which the international community has a responsibility to protect, assist, and/or respond. Climate change, the original core of Common Concern, certainly has such characteristics, but so do other global problems. Former Secretary General Kofi Annan's idea of "human security" captures this: extensive famine, natural catastrophes, and wide-spread epidemics of contagious disease have both such

\footnotetext{
${ }^{30}$ Anne Peters, The Security Council's Responsibility to Protect, 8 Int'l Org L. Rev. at 3 (2011).

${ }^{31}$ SecRes 1973, 17 March 2011.

32 See Philipp Aerni, Thomas Cottier, Baris Karapinar, Sofya Matteotti, Anrirudh Shinghal, Common Concern and Global Public Goods: Evidence, Bits and Pieces, NCCR Working Paper 2012 (forthcoming).
} 
severe impacts on individuals that the international system's interest in protecting the fundamental right to life makes them clear qualifiers for being of Common Concern and the inability of a single government (usually the one with jurisdiction over the victims) to adequately redress the problem can push the Common Concern into one that engages the responsibility of the international community to assist.

But Common Concerns can be more than the bundle of the human rights to life. Flagrantly unresponsive government and chronic public corruption are also of concern to the broader international community, are also problems that cannot be resolved by the territorial authority. Common Concern could further extend to massive financial instability, extremely high levels of unemployment, perhaps even to unsustainable levels of public debt. Given the interconnectedness of the global financial network, such situations undoubtedly affect (or have the potential to affect) states and individuals anywhere on the planet. Regulators from one jurisdiction cannot prevent economic risks - could the international community have a responsibility to call attention to the situation's possible effects, to attempt to encourage the governing authority to act to minimize the risks, or to offer financial assistance where damages have already been incurred? We do not want to answer this question for the international community, but we could suggest that the question not be dismissed out of hand on the basis of a pre-conceived limitation of legal principles that have been carved out of concepts driven by a desire to radically improve the conditions of life for all.

Common Concern, moreover, could also develop into a foundation for responsibilities if obligations at cooperation are not met. It offers a foundation of responsibilities to act beyond borders and to pursue the production of these global public goods in granting authority to States to act extraterritorially. ${ }^{33}$ It will be a matter of defining the scope of such jurisdiction to prescribe, enact and enforce in light of existing international obligations, such as WTO rules and other principles of international law, in particular the principle of proportionality. ${ }^{34}$ Measures taken in pursuit of, and addressing, Common Concern should be appropriate in form and substance, and not transgressing what is required to achieve goals defined by Common Concern. But clearly, there is the potential to move beyond vague concepts of Common Concern and develop more precise principles and perhaps even future rules on cooperation and unilateral action failing efforts at cooperation, for example in the fields of climate change mitigation and adaptation. ${ }^{35}$

\footnotetext{
33 See Thomas Cottier, The Principle of Common Concern : A Brief Outline, in Ernst U. Petersmann, ed., Multilevel Governance of Interdependent Public Goods: Theories, rules and institutions for the central policy challenge in the 21 st Century (forthcoming 2012)

${ }^{34}$ See Thomas Cottier, Roberto Echandi, Rafael Leal-Arcas, Rachel Liechti, Charlotte Sieber-Gasser, The Principle of Proportionality in International Law, in: Alexia Herwig et al eds., (forthcoming)

${ }^{35}$ Cf. Philipp Aerni, Bertram Boie, Thomas Cottier, Kateryna Holzer, Dannie Jost, Baris Karapinar, Sofya Matteotti, Olga Nartova, Tetyana Payosova, Luca Rubini, Anirudh Shingal, Fitzgerald Temmerman, Elena Xoplaki, Sadeq Z.Bigdeli, ' Climate Change and International Law: Exploring the Linkages between Human Rights, Environment, Trade and Investment, 53GYIL 139-188 (2010).
} 


\section{B. Responsibility to Protect}

The Principle of Responsibility to Protect, as stated above, has been severely limited by the political statements of key players in the international law system. ${ }^{36}$ This principle, about which Luck says "the good news is that little or no opposition to ... remains", is the 2009 three-pillar version of R2P. That is, that the state itself has the primary obligation of preventing situations from developing that would lead to the perpetration of genocide, war crimes, ethnic cleansing, and crimes against humanity and protect their populations in situations in which such crimes are being committed (Pillar One); that the international community should cooperate with and assist states in carrying out the responsibilities of Pillar One (Pillar Two); and, finally, that the international community is to act promptly to stop the commission of any of the four crimes, should they begin on account of or despite the local government's actions.

The duties of prevention, prevention, and rebuilding that remain essential to the principle are clearly important. In particular, the emphasis on the preventative aspects that has developed over R2P's short lifespan is a welcome expansion in the application of the concept. A committed use of the international community's duty of prevention could eliminate the need for resorting to the third pillar at all, while extending the list of relevant players. International financial institutions as well as civil society and the private sector become important when matters of the prevention of conflict and violence arise, as all can contribute to the internal strength of a society.

The concept of R2P, however, remains one the scope of which could be greatly extended. ${ }^{37}$ Addressing the R2P Principle only to situations of genocide, war crimes, ethnic cleansing, and crimes against humanity may have been a politically expedient first step, this limitation needs to be read flexibly to ensure its lasting relevance in a world that is quickly adopting a more cosmopolitan view of the goals of international law. Given that individual suffering is not dependent on the fact that thousands of others are suffering similarly or that there is no particular perpetrator of the suffering, the current restriction on the accepted scope of R2P can only be justified by seeing the Principle as a careful step forward along the existing path of legal development. ${ }^{38}$

Already suggested by the drafters of the ICISS Report, applying R2P to issues of Human Security broadly defined would be logical as well as desireable from the viewpoint of the beneficiaries of the Responsibility. Given that individual suffering is not dependent on the fact that thousands of others are suffering similarly or that there is no particular perpetrator of

\footnotetext{
${ }^{36}$ Edward C. Luck, Special Advisor to the UN Secretary-General, describes this process positively as one that made the principle stronger and "more focused" as well as more "nuanced". Luck, Global Responsibility to Protect at 389.

${ }^{37}$ Interestingly, Luck himself calls attention to the difference between addressing the "standard or principle" of R2P and addressing R2P “as a policy or guide to tactical choices”. Luck, Global Responsibility to Protect at 389.

${ }^{38}$ This is, in fact, exactly what the 2009 SG Report does. See para. 2 (emphasizing that paragraphs 138 and 139 were "Based on existing international law"); para. 3 ("the provisions of paragraphs 138 and 139 of the Summit Outcome are firmly anchored in well-established principles of international law").
} 
the suffering, the current restriction on the accepted scope of R2P can only be justified by seeing the Principle as an emphatic restatement of existing law. ${ }^{39}$ Yet, if the development of the international legal order is to be for the benefit of individuals, including the situations of the more than one billion people living in absolute poverty, the over 30 million individuals living with $\mathrm{HIV}^{40}$, and the estimated 2.5 million victims of human trafficking ${ }^{41}$ revisiting the scope of R2P has to be imaginable.

The main conceptual argument against the expanding R2P's dictates beyond the four crimes already included is that of the potential unlimitedness of its scope: if R2P duties were imposed in response to a focus on preventing or relieving the harm to the potential victim, it could apply to situations in which, for instance, thousands of people are threatened by an impending famine. If that were the case, what arguments could prevent states/the international community from having a duty to act to assist the thousands of others who are suffering from AIDS? And if those are to be helped, how can a state credibly argue that the threat of genital mutilation facing the girl-children of another population is not a threat? And should the UN require mobilization in response to a government's unwillingness to fund primary schools adequately? Or its refusal to prosecute corrupt public officials? Certainly, the argument goes, any human rights violation is bad for the victim, but not every human rights violation can be the trigger for required community action.

From a political point of view, these arguments are defensible. ${ }^{42}$ Despite the high value given to human rights law, a perfect record of compliance with such individual protections is by no means the sole goal of the international community. And financing such a program of zerotolerance for violations would be inconceivable even if the political will to do so existed.

If R2P is viewed as mainly about the responsibility of the international community to prevent or respond to situations of grave consequence to individuals due to the harm to the community itself, however, the arguments about extension must be different. There, the limitation on scope must be that preventing the enumerated crimes is necessary to protect community values - and that no other situations are dangerous enough to warrant the potential for infringing on traditional conceptions of sovereignty that an R2P action would entail.

The legal arguments for this approach are that there is enough accepted law regarding genocide, war crimes, crimes against humanity and ethnic cleansing to make the taking on of responsibility in these cases acceptable to governments. There is so much existing law out

\footnotetext{
${ }^{40}$ UNAIDS, World Aids Day Report 2011, 6 (2011) (estimates from end of year 2010).

${ }^{41}$ UNODC, Human Trafficking FAQs (available at www.unodc.org, last viewed 17 May 2012).

${ }^{42}$ Slippery slope arguments are tenuous. Many laws are designed to be generally applicable to a unknowable set of future circumstances, their scope of obligations and rights is amenable to delimitation, and principles of interpretation exist to ensure that such delimitation occurs in accordance with generally accepted practices. Determining the scope of R2P is not fundamentally different than determining the scope of any other new principle. Once the underlying theory of why the principle exists is determined, the limits of the scope can evolve. It need not be predetermined.
} 
there to support the creation of a responsibility to protect, assist, and respond, in fact, that R2P need not be seen as breaking out of any trajectories in international legal development when so limited.

But the argument that there are no other situations with such acceptance begs the question. And here is where Common Concern as defined above enters. Common Concern expressing fundamental community interests could function as the basic framework for determining which situations could be potentially considered worthy of the sovereignty-trumping potential of R2P. Perhaps R2P could apply to severe cases, triggering obligations to act to counter them? Common Concern thus would provide both legitimacy and limitation to international responsibility and to extraterritorial effects of action taken in accordance with the principle of proportionality in defense of shared values and interest of the global community. We still are left with the problem of defining those areas where an obligation to act - different from a right to act - takes effect. We are still left with the challenge do identify those constellations beyond the four crimes where R2P applies as a rule and obligation. Extending and narrowing it to the realm of Common Concerns offers a first step.

In conclusion, there is nothing in the concept itself that would speak against an expansion of R2P within a framework defined by a future principle of Common Concern. While the practicality of extending obligations to address a large circle of threats can be doubted, recent experience has demonstrated that this is equally true of garnering real support for taking action in territories where genocide looks imminent. If anything, the amount and types of resources necessary to address the less violent human security issues might in fact be politically easier to secure. 